\title{
Analysis of Sea Surface Temperature and Its Correlation with Changes in Coastlines Using Landsat 8 Satellite Image Data (Case Study: Ujung Pangkah Gresik)
}

\author{
Hendrata Wibisana *, Zetta R. Kamandang, Siti Zainab \\ Civil Engineering, Universitas Pembangunan Nasional “Veteran” Surabaya, East Java, Indonesia
}

${ }^{*}$ Corresponding author:

E-mail: hendrata.ts@upnjatim.ac.id

\begin{abstract}
Changes in the coastline are a natural phenomenon that often occurs on various coasts where this event has a further effect in the form of sedimentation and erosion along the coast. As a result of this phenomenon, the coast is said to be dynamic towards the various changes that occur, and one of them is the change in sea surface temperature. The purpose of this research is to find a correlation of changes in sea surface temperature to changes in the existing shoreline on the coast of Ujung Pangkah Gresik in addition to calculating the speed of change of the coastline. The method used is the use of remote sensing technology to analyze sea surface temperature and geographic information systems to analyze changes in coastlines. The results obtained from this study are changes in sea surface temperature statistically affect changes in coastlines with an error rate of $5 \%$ at the 20 measured observation points. The model used in sea surface temperature is a linear model with an R-value of 0.783 , and the change in the coastline at Ujung Pangkah Gresik is 153 meters per year measured between 2019 and 2020. The conclusion obtained from this study is that the increase in sea surface temperature will affect climate change on the coast and will ultimately affect changes in the coastline.
\end{abstract}

Keywords: coastline change, sea surface temperature, geographic information system, landsat 8, Ujung Pangkah Gresik

\section{Introduction}

The coastline changes in an area are natural events that have an impact in the form of erosion or sedimentation (Gomez et al., 2019). This change in the coastline is a unique phenomenon and is often used as research material because its growth from year to year will cause changes in the morphology of the coastline. There have been many studies that discuss changes in the coastline, both using conventional methods and by utilizing remote sensing

From several studies that have been carried out, changes in the coastline are largely influenced by seawater currents, waves, and wind direction which will determine the direction of sedimentation travel until it accumulates at a place on the coast (Guzman, Ramos, \& Dastgheib, 2020; Hu et al., 2016; Vaidya, Kori, \& Kudale, 2015; Zhou et al., 2019). Moreover, climate change that occurs also contributes to changes in coastlines, one of which is changes in sea surface temperature. This phenomenon has been studied by several scientists in various parts of the country, the changes in sea surface temperature will have an impact on the existing troposphere in the form of changes in rainfall, changes in air humidity, while in seawater itself these changes will also disturb the biota in it (Bi et al., 2018; Kong et al., 2019; Tang et al., 2019; Yuan, Salama, \& Su, 2018; Zhang et al., 2019). Furthermore, changes in sea surface temperature are predicted to be able to have an impact on changes in wind direction which will change the direction of seawater currents, so that in a few decades changes in coastlines will also be affected (Nazeer et al., 2020).

How to cite:

Wibisana, H., Kamandang Z, R., \& Zainab, S. (2020). Analysis of sea surface temperature and its correlation with changes in coastlines using landsat 8 satellite image data (case study: Ujung Pangkah Gresik). $1^{\text {st }}$ International Conference Eco-Innovation in Science, Engineering, and Technology. NST Proceedings. pages 57-63. doi: 10.11594/ nstp.2020.0508 
Research on sea surface temperature has been conducted by many researchers as well as the process of coastline change, so it will be quite interesting to see whether this sea surface temperature has anything to do with coastline changes, especially when being viewed from climate change which results in changes in seawater temperature and also affect the direction of the wind and currents and waves on the coast.

The purpose of this study is to see the distribution of sea surface temperature in the Ujung Pangkah area and also its effect on changes in the existing coastline, whether there is a significant relationship between the two phenomena, and how the model of the relationship can occur.

\section{Material and Methods Research location}

The location of this research is the Ujung Pangkah Gresik area which has coordinates $7^{\circ} 34^{\prime} 23^{\prime \prime}$ to $-7^{\circ} 48^{\prime} 53^{\prime \prime}$ South Latitude and $112^{\circ} 13^{\prime} 43^{\prime \prime}$ to $112^{\circ} 25^{\prime} 38^{\prime \prime}$ East Longitude. The northern part of Ujung Pangkah is bordered by the Java Sea, the western part is bordered by the Lamongan district, the eastern part is bordered by the Madura Strait and the south by the city of Gresik (Figure 1).

\section{Satellite image}

The satellite imagery used in this study is the Landsat 8 OLI surface reflective satellite image which taken on 8 February 2020 path 118 and row 65 from the web page https://earthexplorer.usgs.gov/. The downloaded file is named by LC08_L1TP_118065_20171230_20180103_01_T1_sr_band2 with 7 channels in it, channel 1 to channel 7, but channel 8 panchromatic not included in the file.

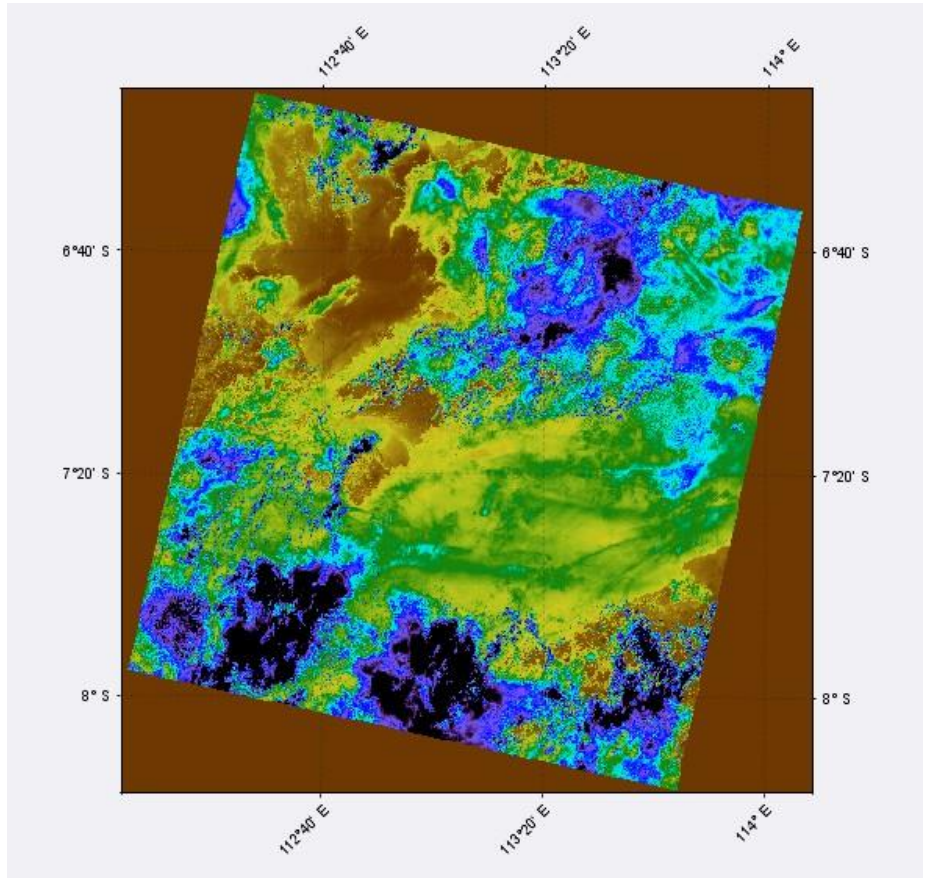

Figure 1. Landsat 8 satellite image with the Ujung Pangkah Gresik interest area

\section{Sea surface temperature}

For sea surface temperature measurements, records are made using a digital thermometer which is fired directly at the surface of seawater in the coastal area. Measurements were made at 20 different points with a distance of 100 meters from each point. The value of sea surface 
temperature obtained is then taken as many as 15 points for measurements with a remote sensing algorithm to obtain a suitable mathematical model that will describe the distribution of sea surface temperature in the area. The final result of this measurement is given in the form of a thematic map of sea surface temperature in the appropriate algorithm involving the existing wavelengths.

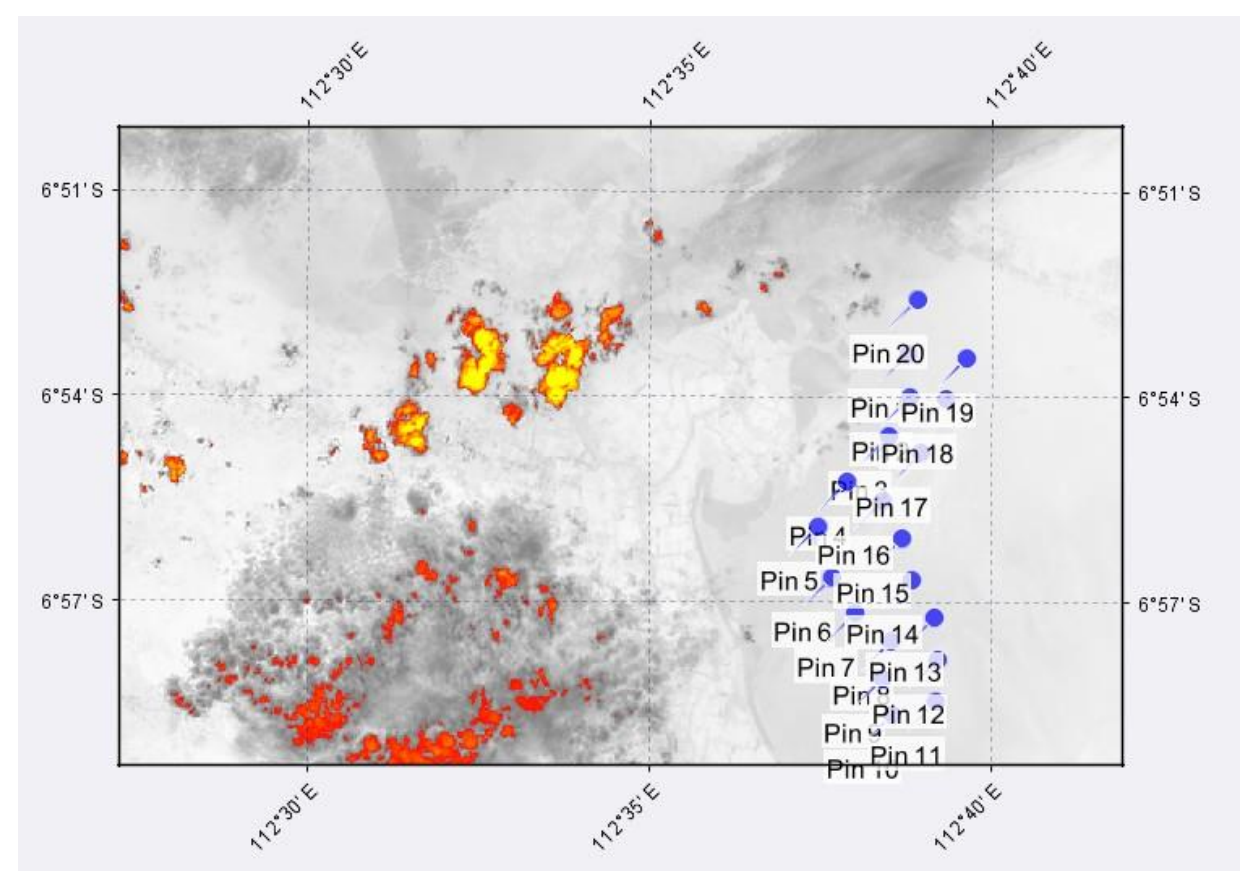

Figure 2. The location of the coordinates of field data collection from sea surface temperature

\section{Coast changes}

To measure the coastline, it is done by digitizing the shoreline at the end of the Ujung Pangkah area which is parallel to the place where the sea surface temperature is taken. The digitization process is carried out using Landsat satellite imagery in 2020 and to measure changes in the shoreline, satellite imagery in 2019 is also used. After that, a comparison of the length of the entire coastline measured between the two years and the results are recorded.

\section{Results and Discussion}

The results obtained from sea surface temperature values are shown in Table 1, wherein the table the latitude and longitude coordinates are included which are adjusted to the data collection points in the field. The SST value obtained has a minimum value of $25.7^{\circ} \mathrm{C}$ and the highest value of $30.8^{\circ} \mathrm{C}$, in general, this condition is normal for a marine environment that is not dominated by large waves because Ujung Pangkah is located in the northern coast of East Java which is only influenced by the Java sea, in contrast to areas influenced by the South Coast.

Furthermore, from the data in Table 1, remote sensing algorithm processing is conducted to obtain the best mathematical model of sea surface temperature and with a scatter diagram, the analysis results show that the SST algorithm for the Ujung Pangkah area is linear with a correlation value of $\mathrm{R}$ of 0.9286 . This value is obtained at a wavelength of 667 nanometers. 
Table 1. Coordinate results and field data from sea surface temperature

\begin{tabular}{|c|c|c|}
\hline Longitude & Latitude & $\operatorname{SST}\left({ }^{\circ} \mathrm{C}\right)$ \\
\hline 112.6392 & -6.8966 & 30.8 \\
\hline 112.6396 & -6.9072 & 30.4 \\
\hline 112.6344 & -6.9167 & 28.7 \\
\hline 112.6244 & -6.9279 & 27.3 \\
\hline 112.6174 & -6.9387 & 27.5 \\
\hline 112.6207 & -6.9512 & 28.6 \\
\hline 112.6264 & -6.9599 & 26.4 \\
\hline 112.6351 & -6.9666 & 26.7 \\
\hline 112.6330 & -6.9758 & 25.9 \\
\hline 112.6355 & -6.9845 & 26.2 \\
\hline 112.6461 & -6.9812 & 27.4 \\
\hline 112.6466 & -6.9712 & 25.7 \\
\hline 112.6457 & -6.9609 & 26.1 \\
\hline 112.6403 & -6.9517 & 25.8 \\
\hline 1126378 & -6.9416 & 26.5 \\
\hline 112.6331 & -6.9324 & 26.8 \\
\hline 112.6423 & -6.9207 & 27.4 \\
\hline 112.6485 & -6.9077 & 27.1 \\
\hline 112.6534 & -6.8976 & 26.8 \\
\hline 112.6414 & -6.8833 & 28.2 \\
\hline
\end{tabular}


Table 2. Resume of the mathematical model at $667 \mathrm{~nm}$ wavelength

\begin{tabular}{cccc}
\hline No & Algorithm & Mathematical Model & R2 \\
\hline 1 & Linear & SST $=74.49 \mathrm{x}+22.414$ & 0.9286 \\
2 & Exponent & SST $=22.91 \mathrm{e}^{2.6492 \mathrm{x}}$ & 0.9253 \\
3 & Logarithmic & $\mathrm{SST}=5.1707 \ln (\mathrm{x})+41.605$ & 0.8843 \\
4 & Power & SST $=45.403 \mathrm{x}^{0,1844}$ & 0.8864 \\
\hline
\end{tabular}

Source: result from the calculation

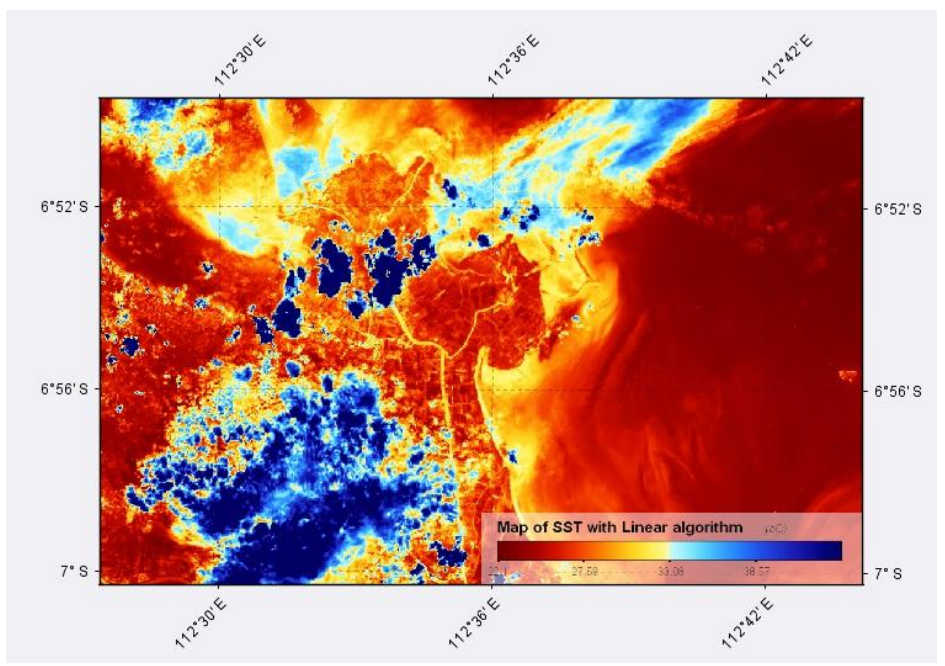

Figure 3. Thematic map of SST from linear algorithm at 667-nanometer wavelength

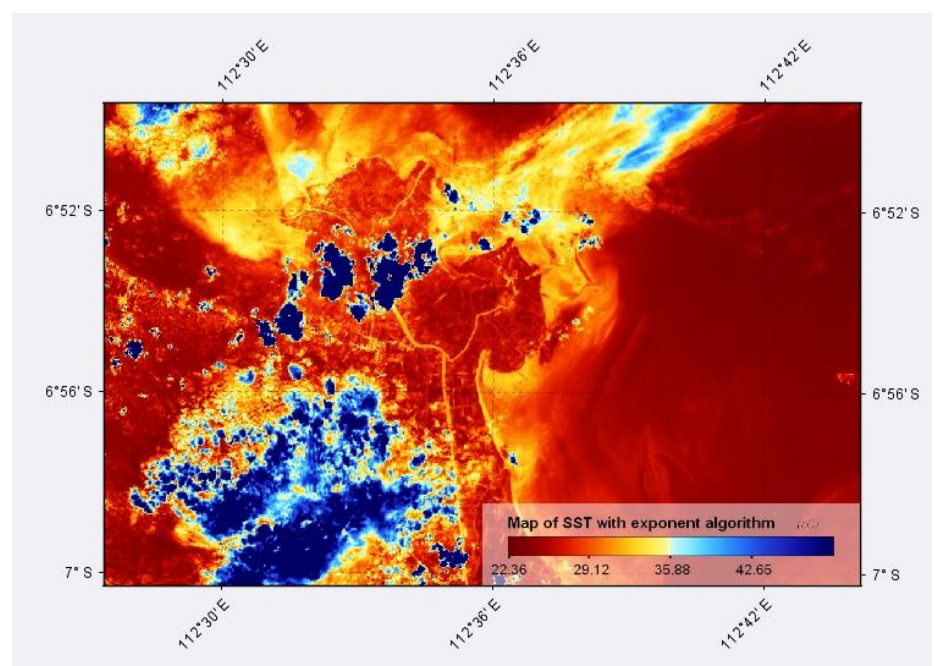

Figure 4. Thematic map of SST from exponent algorithm at 667-nanometer wavelength 


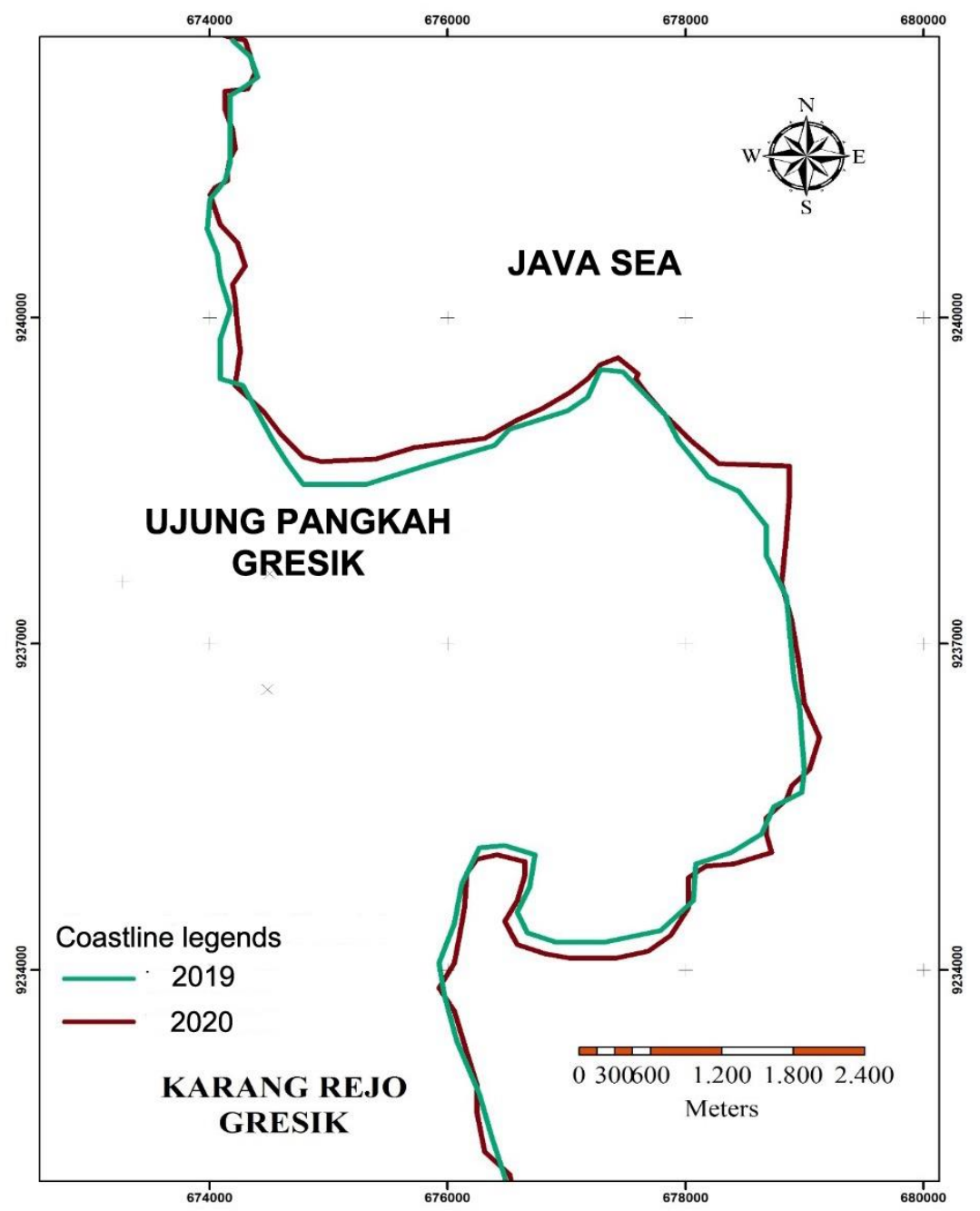

Figure 5. Coastline changes from 2019-2020 at Ujung Pangkah Gresik

From Figure 5, it can be seen that the length of the Ujung Pangkah coastline, where for 2019 the measured is 20051.01 meters and for 2020 the measured length is 20878.517 meters. From the two data, there is a difference of 827.507 meters, this shows that during the period of one year the coastline at Ujung Pangkah increased in length by this value, in that area, especially in the curved area, there was a fairly large and continuous sedimentation process from year to year.

\section{Conclusion}

Sea surface temperature has characteristics that depend on the existing climate, from the resulting mathematical model, it is found that the best model to describe the SST distribution is a linear model as seen from the magnitude of the $\mathrm{R}$ correlation value. This mathematical model has a positive gradient so that every increase in the reflectance value from the Landsat image will increase the value of sea surface temperature, this is in line with changes in the coastline where changes during the year are getting bigger. So, it can be said that changes in sea surface temperature are directly proportional to changes in coastlines for the conditions of the Ujung Pangkah Gresik area. 


\section{Acknowledgment}

The author would like to thank the LPPM UPN Veteran Jawa Timur for providing Batch 1 research funds with Contract Number: SPP / 34 / UN.63.8 / LT / V / 2020, therefore, this research can be completed on time and provide good results. Thanks also to the students who have helped a lot in obtaining field data.

\section{References}

Bi, S., Li, Y., Wang, Q., Lyu, H., Liu, G., Zheng, Z., Du, C., Mu, M., Xu, J., Lei, S., \& Miao, S. (2018). Inland water Atmospheric Correction based on Turbidity Classification using OLCI and SLSTR synergistic observations. Remote Sensing, 10(7), 12-19. https://doi.org/10.3390/rs10071002

Gomez, C. A., Hart, D. E., Wassmer, P., Kenta, I., Matsui, H., \& Shimizu, M. (2019). Coastal evolution, geomorphic processes and sedimentary record in the Anthropocene. Forum geografi, 33(1), 1-10. doi: 10.23917/forgeo.v33i1.7551

Guzman, E., Ramos, C., \& Dastgheib, A. (2020). Influence of the El Niño Phenomenon on Shoreline Evolution. Case Study: Callao Bay, Perú. Journal of Marine Science and Engineering, 8(2), 90. https://doi.org/10.3390/jmse8020090

Hu, Z., Pan, D., He, X., \& Bai, Y. (2016). Diurnal variability of turbidity fronts observed by geostationary satellite ocean color remote sensing. Remote Sensing, 8(2). https://doi.org/10.3390/rs8020147

Kong, F., Dong, Q., Xiang, K., Yin, Z., Li, Y., \& Liu, J. (2019). Spatiotemporal variability of remote sensing ocean net primary production and major forcing factors in the tropical eastern Indian and Western Pacific Ocean. Remote Sensing, 11(4). https://doi.org/10.3390/rs11040391

Nazeer, M., Waqas, M., Shahzad, M. I., Zia, I., \& Wu, W. (2020). Coastline Vulnerability Assessment through Landsat and Cubes ats in a Coastal Mega City. Remote Sensing, 12(5), 749. https://doi.org/10.3390/rs12050749

Tang, Q., Wang, S., Qiu, Z., Sun, D., \& Bilal, M. (2019). Variability of the suspended particle cross-sectional area in the Bohai Sea and Yellow Sea. Remote Sensing, 11(10). https://doi.org/10.3390/rs11101187

Vaidya, A. M., Kori, S. K., \& Kudale, M. D. (2015). Shoreline Response to Coastal Structures. Aquatic Procedia, 4(2015), 333-340. https://doi.org/10.1016/j.aqpro.2015.02.045

Yuan, X., Salama, M. S., \& Su, Z. (2018). An observational perspective of sea surface salinity in the Southwestern Indian Ocean and its role in the South Asia Summer Monsoon. Remote Sensing, 10(12), 220-229. https://doi.org/10.3390/rs10121930

Zhang, H., Liu, X., Wu, R., Liu, F., Yu, L., Shang, X., Qi, Y., Wang, Y., Song, X., Xie, X., Yang, C., Tian, D., \& Zhang, W. (2019). Ocean response to successive typhoons Sarika and Haima (2016) based on data acquired via multiple satellites and moored array. Remote Sensing, 11(20), 123-128. https://doi.org/10.3390/rs11202360

Zhou, M., Wu, M., Zhang, G., Zhao, L., Hou, X., \& Yang, Y. (2019). Analysis of coastal zone data of northern Yantai collected by remote sensing from 1990 to 2018. Applied Sciences (Switzerland), 9(20), 35-42. https://doi.org/10.3390/app9204466 